\title{
ANALISIS KESALAHAN DALAM MENYELESAIKAN SOAL-SOAL OPERASI BENTUK ALJABAR PADA SISWA KELAS VIII SMP NEGERI 5 KENDARI
}

\author{
Santi Rusmiati ${ }^{\text {(), Sriwati Dangga }}{ }^{2)}$ \\ ${ }^{1,2)}$ SMP Negeri 5 Kendari \\ Email: santirusmiati28@ gmail.com ${ }^{1)}$;sriwati@gmail.com ${ }^{2)}$
}

\begin{abstract}
Abstrak
Penelitian ini bertujuan untuk mengetahui kesalahan yang dilakukan siswa dalam menyelesaikan soal bentuk aljabar, untuk mengetahui penyebab-penyebab siswa melakukan kesalahan dalam menyelesaikan soal bentuk aljabar. Jenis Penelitian ini adalah deskriptif kualitatif. Subjek penelitian dipilih berdasarkan hasil analisis dan data tes sebanyak 30 orang siswa. Hasil analisis data tes digunakan sebagai dasar pemilihan subjek wawancara dan dipilih 4 orang siswa. Analisis data dilakukan melalui langkah-langkah menelaah seluruh data, reduksi data, penyajian data, dan verifikasi data. Data hasil wawancara digunakan sebagai pembanding data hasil tes untuk mengetahui penyebab siswa melakukan kesalahan. Kesimpulan yang diperoleh dari penelitian ini adalah: Jenis kesalahan yang dilakukan siswa kelas VIII ${ }_{D}$ SMP Negeri 5 kendari dalam menyelesaikan soal operasi aljabar adalah kesalahan fakta, kesalahan konsep, kesalahan prinsip dan kesalahan prosedural, Faktor-faktor yang menyebabkan siswa melakukan kesalahan dalam menyelesaikan soal operasi aljabar yaitu siswa tidak memahami soal dengan baik, sehingga siswa tidak dapat menerjemahkan suatu permasalahan kedalam model matematika.
\end{abstract}

Kata Kunci: analisis kesalahan siswa, objek matematika, hasil jawaban siswa

\section{ANALYSIS OF ERRORS IN COMPLETING OPERATING PROBLEMS FOR ALGEBRAIC FORMS IN GRADE VIII STUDENTS Of SMP NEGERI 5 KENDARI}

\begin{abstract}
This study aims to determine the mistakes made by students in solving algebraic form questions, to determine the causes of students making mistakes in solving algebraic form questions. This type of research is descriptive qualitative. The research subjects were selected based on the results of the analysis and test data of 30 students. The results of the test data analysis were used as the basis for selecting interview subjects and selected 4 students. Data analysis was carried out through the steps of examining all data, data reduction, data presentation, and data verification. Interview data is used as a comparison of test result data to find out why students make mistakes. The conclusions obtained from this study are: The types of errors made by students of class VIII ${ }_{D}$ SMP Negeri 5 Kendari in solving algebraic operation problems are fact errors, concept errors, principle errors and procedural errors, the factors that cause students to make mistakes in solving operation problems algebra, namely students do not understand the problem well, so students cannot translate a problem into a mathematical model.
\end{abstract}

Keywords: student error analysis, mathematical objects, student answer results 


\section{Pendahuluan}

Pendidikan merupakan sarana seseorang untuk menunjuk kearah yang lebih baik dan pada masa sekarang ini pendidikan merupakan kebutuhan yang memiliki peranan penting dalam mengahasilkan generasi muda yang berkualitas dan berdaya saing. Pendidikan juga memegang peranan yang sangat penting untuk menjamin keberlangsungan hidup suatu negara. Di Indonesia, setiap usaha pendidikan harus sesuai dengan fungsi dan tujuan pendidikan nasional seperti yang tertulis dalam Undang-Undang sistem pendidikaan tahun 2003, yakni pendidikan nasional berfungsi mengembangkan kemampuan dan membentuk watak serta peradaban bangsa yang bermartabat dalam rangka mencerdaskan kehidupan bangsa, bertujuan untuk berkembangnya potensi peserta didik agar menjadi manusia yang berilmu, cakap, kreatif, mandiri, dan menjadi warga Negara yang demokratis serta bertanggung jawab (Depdiknas, 2006: 3)

Seiring dengan ditingkatkannya mutu pendidikan di Indonesia, tetapi masih ditemukannya kesalahan siswa dalam menyelesaikan soal-soal atau permasalahan. siswa tersebut dapat berdampak pada pemahaman siswa untuk memahami suatu materi, terkhusus pada bidang studi matematika. Untuk bidang studi matematika, tingkat pemahaman siswa terhadap suatu materi itu masih sangat rendah. Selain prestasi matematika yang rendah, masalah yang perlu menjadi perhatian berkaitan dengan pelajaran matematika adalah banyaknya kesalahan yang dilakukan siswa dalam menyelesaikan soal-soal matematika. Kesalahan-kesalahan umum yang sering dilakukan siswa dalam meyelesaikan soalsoal matematika diantaranya adalah, kesalahan dalam memahami konsep matematika, kesalahan dalam menggunakan rumus matematika, kesalahan hitung atau komputasi, kesalahan dalam memahami simbol dan tanda, kesalahan dalam memilih dan mengunakan prosedur penyelesaian.

Selain matematika dianggap sulit bagi sebagian besar siswa, matematika juga mempunyai karakteristik yang berbeda dengan pelajaran lain. Menurut Soedjadi (2002 : 2) karakteristik matematika adalah memiliki objek abstrak, bertumpu pada kesepakatan, berpola pikir deduktif, memiliki simbol yang kosong arti, memperhatikan semata pembicaraan, dan konsisten dalam sistemnya. Dengan berbagai karakteristik matematika tersebut, banyak siswa mengalami kesulitan dalam mempelajari matematika, sehingga banyak siswa yang melakukan kesalahan menyelesaikan soal-soal matematika yang diberikan.

Beberapa kesalahan yang dilakukan siswa dalam menyelesaikan soal-soal matematika dipengaruhi oleh beberapah hal. Salah satu sebabnya yaitu sangat kompleksnya konsepkonsep matematika. konsep matematika itu, sering kali dalam penyajiaanya tanpa diimbangi dengan cara penyampainnya yang baik oleh guru. Artinya, ketika menyampaikan konsep matematika, guru kurang memperhatikan tingkat perkembangan psikologis anak. Dengan demikian, terjadi celah antara keinginan guru dengan fakta kemampuan anak dalam memahami konsep matematika. Hal ini sejalan dengan apa yang di kemukakan oleh Sahriah dkk (2012 : 2) bahwa konsep-konsep matematika tersusun secara hirarkis, terstruktur, logis dan sistematis mulai dan konsep yang paling sederhana sampai pada konsep yang paling kompleks. Hal ini berarti bahwa didalam matematika terdapat konsep prasyarat. Konsep ini merupakan dasar untuk memahami suatu topik atau konsep selanjutnya.

Kesalahan sebenarnya merupakan hal yang wajar dilakukan namun apabila kesalahan yang dilakukan cukup banyak dan berkelanjutan, maka diperlukan penangganan. Begitu juga dalam mempelajari matematika merupakan suatu hal yang wajar apabila dalam menyelesaikan soal matematika, siswa melakukan kesalahan. Namun apabila kesalahan-kesalahan yang muncul tidak segera mendapat perhatian dan tidak lanjut, akan berdampak buruk bagi siswa.

Salah satu materi matematika yang sulit dipahami oleh siswa adalah operasi aljabar. Salah satu contonhya adalah dijumpai pada siswa kelas VIII SMP Negeri 5 Kendari yang masih banyak melakukan kesalahan dalam menyelesaikan soal-soal matematika. Berdasarkan hasil observasi awal wawancara dengan guru bidang studi matematika pada tanggal 06 Maret 2018 mengungkapkan bahwa siswa masih sering melakukan kesalahan dalam menyelesaikan soal matematika, begitu pula pada soal materi bentuk aljabar. Dimana masih banyak siswa yang belum mampu menyelesaikan soal yang berkaitan dengan bentuk aljabar. Dan hasil ulangan siswa materi 
bentuk aljabar tahun ajaran 2018/2019 diperoleh nilai rata-rata kelas VIII adalah 70 .

Penelitian ini dilakukan untuk mengetahui kesalahan-kesalahan siswa dalam menyelesaikan soal-soal matematika pokok bahasan bentuk aljabar dengan mencari dan mengidentifikasi kesalahan-kesalahan pengerjaan soal matematika yang dikerjakan siswa berdasarkan langkah pemecahan masalahnya. Penelitian tersebut diberi judul "Analisis Kesalahan Dalam Menyelesaikan Soal-Soal Bentuk Aijabar Pada Siswa Kelas VIII SMP Negeri 5 Kendari”.

\section{Metode}

Penelitian ini dilaksanakan pada tanggal 09 September sampai 16 September 2018 di SMP Negeri 5 Kendari pada kelas VIII dan waktu pelaksanaan ini pada semester ganjil Tahun Pelajaran 2017/2018. Dalam penelitian ini, data yang dihasilkan adalah data deskriptif yang berupa kata-kata tertulis atau lisan. Strategi penelitian yang digunakan adalah metode deskriptif kualitatif. Pada penelitian ini, pengambilan data dilakukan dengan menggunakan tes dan wawancara. Data yang di perolehkan dideskripsikan atau diuraikan kemudian dianalisis.

Perhatian utama dalam penelitian ini adalah hasil tes matematika siswa pada materi pokok Bentuk Aljabar. Hasil pekerjaan siswa tersebut untuk menyajikan jawaban terhadap permasalahan penelitian ini.

Peneiltian ini dilakukan pada siswa kelas VIII SMP Negeri 5 Kendari Semester 1 Tahun
Pelajaran 2017/2018, setelah mempelajari materi pokok bahasan operasi aljabar. Sebelum dijelaskan mengenai subyek penelitian ini, terlebih dahulu dijelaskan keberadaan siswa kelas VIII SMP Negeri 5 Kendari tahun pelajaran 2017/2018 yang terdiri dari 8 kelas parallel. Untuk keperluan penelitian ini, diambil I kelas sebagai sasaran penelitian. Berdasarkan informasi dari guru matematika bahwa penyebaran kelas paralel pada sekolah tersebut tidak berdasarkan pada tingkat kemampuan matematikanya sehingga untuk kepeluan penelitian ini diambil kelasVIII dengan jumlah keseluruhan siswa sebanyak 30 siswa yang terdiri dari 20 siswa laki-laki dan 10 siswa perempuan sebagai subyek penelitian.

Penentuan siswa yang terpllih sebagai subyek yang diwawancarai dalam perhatian ini, dilakukan langkah-Iangkah berikut:

1. Memperhatikan siswa yang banyak membuat kesalahan dalam menjawab setiap butir soal.

2. Memperhatikan kesalahan atau variasi kesalahan yang dilakukan siswa berupa kesalahan dalam memahami konsep dan kesalahan dalam memahami dan menerapkan pninsip serta kesalahan prosedural (konsep, prinsip, operasional, dan fakta).

Berdasarkan kriteria tersebut, maka siswa yang terpilih sebagai subjek penelitian yang akan diwawancarai adalah berjumlah 4 orang siswa. Untuk lebih jelasnya dapat dilihat pada tabel 3.1 berikut:

Tabel 1

Siswa yang Terpilih Sebagai Subjek Penelitian

\begin{tabular}{|c|c|c|}
\hline No. & Nama & Kode \\
\hline 1 & Nur Muhammad & SP-02 \\
\hline 2 & Ersan Saputra & SP-05 \\
\hline 3 & Della Indriani Ashar & SP-29 \\
\hline 4 & Wa Ode Nanang Destriani & SP-30 \\
\hline
\end{tabular}

Analisis data dalam peneltian ini dilakukan selama proses penelitian sampai selesainya pengumpulan data, agar data lebih sistematis dan tidak ada data yang terlupakan sehingga memudahkan peneliti dalam menafsirkannya. Margono (2004: 190) mengemukakan bahwa analisis dalam penelitian kualitatif mengajak seseorang untuk mempelajari masalah yang diteliti secara mendasar dan mendalam sampai keakar-akarya. Masalah yang dilihat dan beberapah segi guna untuk memperoleh data yang berkualitas. Miles dan Huberman (dalam Gunawan, 2013 : 210211) mengemukakan tiga tahapan yang harus dikerjakan dalam menganalisis data penelitian kulitatif, yaitu (1) reduksi data (data reduction); (2) paparan data (data display); (3) penarikan kesimpulan dan verifikasi (conclutiondrawing/verjfying). 


\section{HASIL}

\section{Analisis Hasil Observasi}

Berdasarkan hasil observasi, dapat diketahui bahwa guru memulai pelajaran dengan membagi buku paket dan memberitahukan kepada siswa tentang materi yang akan dipelajari. Sebel̀umnya menjelaskan mengenai materi yang akan pelajari, guru selalu mengingatkan materi yang berkaitan dengan operasi aijabar yang telah dipelajari, guru selalu meningkatkan materi yang berkaitan dengan operasi aljabar yang telah di pelajari pada pertemuan sebelumnya di kelas VII.

Kemudian guru kembali menjelaskan tentang tujuan pembelajaran dan memberikan motivasi kepada siswa. Kemudian, guru menjelaskan mengenai materi operasi aljabar, dan memberikan contoh soal yang ada dalam buku paket yang digunakan, guru membahas penyelesaian dan contoh soal tersebut secara runtut dari awal sampai akhìr dengan sesekali memberikan beberapa pertanyaan kepada siswa. Setelah membahas contoh soal, guru menanyakan kepada siswa mengenai contoh soal yang telah diberikan. Dalam mengajar, guru tidak menggunakan alat bantu belajar khusus seperti alat peraga atau alat bantu lainnya.

Guru memberikan umpan balik terhadap apa yang telah disampaikan dengan menanyakan kepada siswa apakah siswa dapat memahami materi yang telah disampaikan atau belum. Jika siswa masih belum paham, maka guru menjelaskan kembali contoh soal tersebut. Setelah siswa paham materi yang diberikan, guru memberikan soal latihan dan meminta siswa agar mengerjakan soal latihan tersebut.

Secara umum, metode yang digunakan guru adalah metode ceramah, tanya jawab, dan pemberian tugas. Metode ceramah digunakan untuk menjelaskan operasi aljabar dan metode Tanya jawab digunakan saat guru menjelaskan dalam menyelesaikan soal. Metode tugas berupa pemberian soal yang harus dikerjakan oleh siswa, baik dikelas maupun sebagai pekerjaan rumah.

Observasi terhadap siswa dilakukan pada saat siswa menerima pelajaran dengan materi operasi aljabar. Sebelum memulai pelajaran siswa selalu berdoa menurut agama dan kepercayaan mereka masing-masing. Pada umumnya siswa memperhatikan guru yang sedang menjelaskan materi pelajaran. Hanya beberapa siswa yang terlihat kurang memperhatikan pada pelajaran, mereka sibuk menulis atau justru berbicara dengan temannya. Namun setelah di ingatkan mereka kembali memperhatikan penjelasan guru. Siswa mencatat apa yang diberikan guru dipapan tulis, tetapi terkadang ini membuat siswa justru asyik mencatat dan lupa untuk memperhatikan penjelasan guru.

Keaktifan siswa dalam bertanya kepada guru mengenai hal-hal yang belum mereka ketahui sangatlah kurang. Siswa lebih suka bertanya kepada temannya dari pada kepada gurunya tentang materi yang belum jelas. Keaktifan siswa dalam menjawab pertanyaan dan guru pun rendah. Siswa akan menjawab pertanyaan khusus pertanyaan-pertanyaan yang membutuhkan jawaban serentak.

Berdasarkan hasil pekerjaan siswa dalam menyelesaikan soal-soal operasi aljabar dapat ditemukan beberapa kesalahan yang dilakukan siswa. Adapun kesalahan-kesalahan tersebut antara lain:

\section{Analisis Hasil Wawancara}

Berdasarkan kesalahan-kesalahan yang dilakukan siswa dan untuk mengetahui faktorfaktor yang menyebabkan terjadinya kesalahankesalahan tersebut, dipilih beberapa siswa untuk dianalisis jawabannya. Pada deskripsi kesalahan yang dilakukan siswa dalam menyelesaikan soalsoal di atas, siswa dikelompokan berdasarkan jenis kesalahan yang dilakukan siswa ditinjau dari objek matematika yaitu kesalahan fakta, kesalahan konsep, kesalahan prinsip, kesalahan prosedur. Penentuan subjek wawancara dilakukan pada setiap kelompok jenis kesalahan. Pada kelompok jenis kesalahan yang sama, dapat diambil satu atau dua siswa sebagai subjek wawancara yang mewakili kesalahan pada kelompok tersebut. Jawaban pada tes dan hasil wawancara dan empat siswa tersebut dianalisis untuk menentukan kesalahan yang dilakukan beserta penyebabnya. Hasil dan analisis data tes dan analisis data wawancara dibandingkan untuk mendapatkan kesimpulan berupa data yang valid mengenai kesalahan yang dilakukan siswa dan faktor penyebabnya. Kesalahan yang dilakukan siswa dianalisis dengan acuan kesalahan yang ditinjau dari objek matematika. Untuk itu, kesimpulan mengenai kesalahan yang dilakukan siswa harus menunjukan letak kesalahannya yaitu kesalahan fakta, kesalahan konsep, kesalahan prinsip, dan prosedur. Oleh karena itu, 
pada kesimpulan yang diperoleh merupakan hasil triangulasi data.

Wawancara dengan siswa dilakukan untuk menelusuri lebih lanjut tentang kesalahan siswa dalam menyelesaikan soal-soal matematika materi pokok operasi aljabar. Berikut ini akan disajikan analisis hasil wawancara dengan empat orang siswa yang menjadi subjek penelitian (SP). Selain itu, dilakukan pula Wawancara terhadap guru bidang studi matematika yang mengajarkan materi operasi aljabar mengetahui faktor-faktor dan penyebab siswa melakukan kesalahan dalam menyelesaikan soal-soal operasi aljabar.

\section{Analisis Kesalahan Jawaban Siswa Nomor} Subjek 29

\section{Soal Nomor 1}

\section{Analisis Hasil Tes}

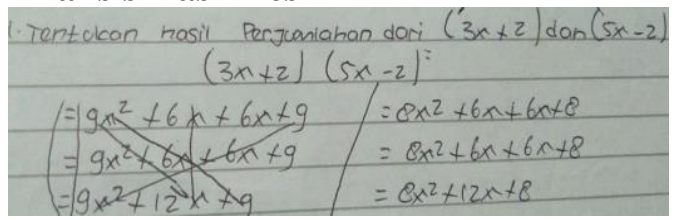

Dari jawaban siswa tersebut tampak bahwa siswa tidak memenuhi apa yang dimaksud dalam soal dan siswa tidak paham dengan konsep penjumlahan.

\section{Analisis Wawancara}

P : Asalamualaikum waroahmatullahi wabaroakaatu

SP : Wa'alaikum salam kak

$\mathrm{P}$ : Sudah bisa kita mulai wawancaranya

SP : Iya kak

$\mathrm{P}$ : Bisa tolong bacakan soalnya nomor 1?

SP : (siswa membaca soal)

$\mathrm{P} \quad$ : Apa yang ditanyakan disini?

SP : Hasil penjumlahan ini dengan yang ini kak. (Sambil menunjuk soal)

P : Terus kenapa ini kamu tulis seperti perkalian?

SP : Saya bingung kak karena ada kurung, jadi saya kira dikali baru dijumlahkan.

Berdasarkan kutipan wawancara tersebut, terlihat bahwa siswa melakukan kesalahan prinsip. Hal ini karena siswa salah dalam menuliskan notasi penjumlahan dan juga siswa salah dalam mengoperasikan bentuk aljabar. Dari analisis hasil tes dan analisis wawancara. Dapat disimpulkan bahwa siswa melakukan kesalahan prinsip karena siswa tidak paham konsep penjumlahan dan juga siswa salah dalam mengoperasikan bentuk aljabar tersebut.

\section{Soal Nomor 2}

Analisis Hasil tes

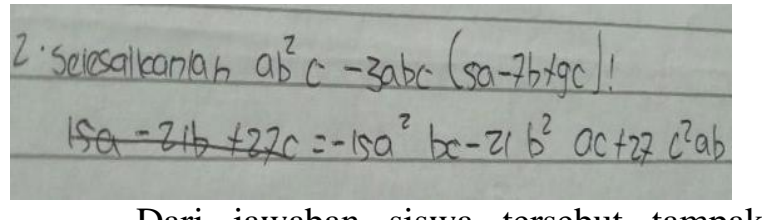

Dari jawaban siswa tersebut tampak bahwa siswa melakukan kesalahan konsep, karena salah dalam mengaitkan antara bilangan negatif dan bilangan negatif serta bilangan negatif dan positif. Hal ini mungkin disebabkan karena siswa kurang teliti dalam mengerjakan soal.

\section{Analisis Wawancara}

$P \quad$ : Dari mana ini jawabanmu $-15 \mathrm{a}^{2}-$ $21 b^{2} a c+27 c^{2} a b ?$

SP : Saya kalikan itu kak

$\mathrm{P} \quad$ : Sudah betul ini

SP : (sambil garuk-garuk kepala) iya kayaknya kak

P : Apa hasilnya kalau bilangan negatif dikali bilangan negatif?

SP : (siswa diam)

$\mathrm{P}$ : Belum pernah kah diajar perkalian begini?

SP : Sudah mi kak tapi saya lupa-lupa mi

Berdasarkan hasil pekerjaan siswa dari kutipan wawancara síswa diatas dapat disimpulkan bahwa siswa melakukan kesalahan konsep yaitu siswa salah dalam menuliskan simbol. Hal ini disebabkan karena siswa belum paham dengan perkalian antara bilangan yang tidak sejenis.

\section{Soal Nomor 3 \\ Analisis Hasil Tes}

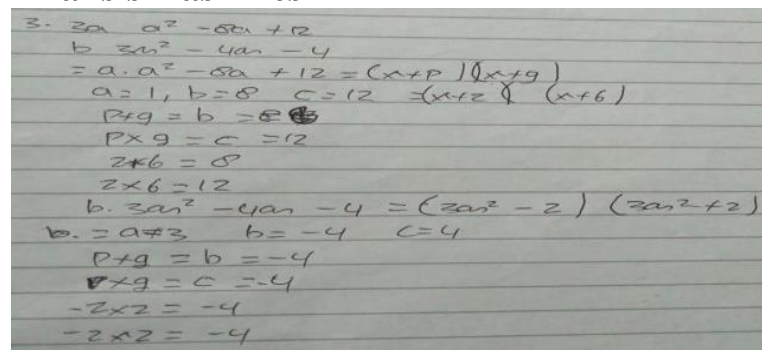

Dari jawaban siswa tampak bahwa siswa melakukan kesalahan sebagai berikut:

1. Siswa tidak menuliskan apa yang diketahui dan apa yang ditanyakan 
2. Pada nomor 3a siswa salah dalam menuliskan nilai b sehingga siswa salah dalam menuliskan jawaban hasil akhir

3. Pada soal 3b, siswa salah dalam menuliskan rumus p.q untuk menentukan faktor-faktor dan aljabar tersebut.

\section{Analisis Wawancara}

$\mathrm{P} \quad$ : Berapa nilai b untuk nomor $3 \mathrm{a}$ ini?

$\mathrm{SP} \quad:-8 \mathrm{kak}$

$\mathrm{P} \quad$ : Kenapa kamu tulis 7 ?

SP : Saya buru-buru kak

$\mathrm{P}$ : Sudah benar nomor $3 \mathrm{~b}$ ini rumusnya $\mathrm{P}+$ Q dengan $\mathrm{P}$ x Q

SP : Sudah benar mi kayaknya kak

$\mathrm{P}$ : Coba bandingkan jawabanmu dengan yang lain (sambil menunjukan kunci jawaban instrument tes)

SP : Beda kak

$\mathrm{P} \quad$ : Dibagian mana yang beda?

SP : Rumus PxQ

$\mathrm{P} \quad$ : Nah jadi begini de, kalau bentuk aljabar $a x^{2}+b x+c$ dengan $a \neq 1$ dan $a \neq 0$ itu rumusnya beda dengan aljabar bentuk $a x^{2}+b x+c$ dengan $a=1$. Kalau yang bentuk aljabar $\mathrm{ax}^{2}+\mathrm{bx}+\mathrm{e}$ dengan $\mathrm{a} \neq 1$ mempunyai faktor $a x^{2}+b x+(a x+p)(a x$ $+\mathrm{q})$ dengan $\mathrm{p}+\mathrm{q}=\mathrm{b}$ p $\cdot \mathrm{q}=\mathrm{ac}$

SP : Oh iya kak berarti jawabanku salah P :Iya de

Berdasarkan kutipan wawancara diatas, dapat disimpulkan bahwa siswa tidak bisa membedahkan rumus $\mathrm{p}+\mathrm{q}$ dan $\mathrm{p}$. q untuk bentuk $\mathrm{ax}^{2}+\mathrm{bx}+\mathrm{c}$ deangana $\neq 1$ dana $\neq 0$ dengan aljabar bentuk $a x^{2}+b x+c$ dengan $a=1$. Hal ini di karenakan siswa tidak pahami dengan konsep pemfaktoran atau prosedural.

\section{Soal Nomor 4}

\section{Analisis Hasil Tes}

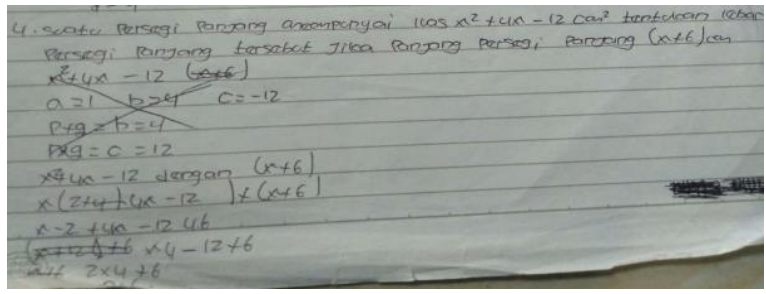

Dari jawaban siswa tampak bahwa diatas siswa mengerjakan soal tidak sesuai dengan apa yang diminta dalam soal. Hal ini mungkin dikarenakan siswa tidak paham dengan konsep persegi panjang dan juga siswa tidak paham apa yang ditanyakan dalam soal.

\section{Analisis Wawancara}

$\mathrm{P} \quad$ : Apa-apa yang diketahui dinomor 4 ini?

SP : Suatu persegi panjang mempunyai luas $\mathrm{x}^{2}+4 \mathrm{x}-12 \quad \mathrm{~cm}^{2}$. Tentukan lebar persegi panjang tersebut $\mathrm{j}$ ika panjang persegi panjang $(\mathrm{x}+6) \mathrm{cm}$

$\mathrm{P} \quad$ : Iya, jadi apa yang diketahui ini?

SP : Luas sama panjangnya kak

$\mathrm{P} \quad$ : Apa yang ditanyakan?

SP : Tentukan lebar persegi panjang kak

$\mathrm{P} \quad$ : Bisa kamu jelaskan jawabanmu ini?

SP : Kayaknya jawabanku salah

$\mathrm{P} \quad$ : Jadi bagaimana harusnya?

SP : (siswa diam)

Berdasarkan Hasil Tes dan kutipan wawancara tersebut, dapat disimpulkan bahwa siswa melakukan kesalahan konsep dalam mengubah permasalahan kedalam model matematika. Hal ini dikarenakan siswa kurang teliti dalam mengerjakan soal.

\section{Analisis Kesalahan Jawaban Siswa Nomor Subjek 30}

Soal Nomor 1

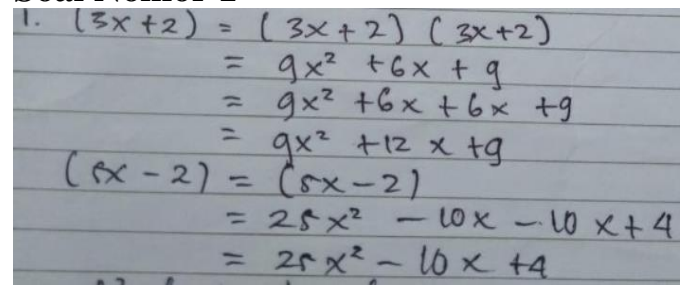

Dari jawaban siswa tampak bahwa siswa melakukan kesalahan dalam memaknai soal. Siswa mengerjakan soal penjumlahan dengan cara mengalikan terlebih dahulu setiap suku dengan dirinya sendiri kemudian mengurangkan. Hal ini mungkin dikarenakan siswa tidak paham dengan apa yang dimaksud dalam soal dan juga siswa tidak paham dengan konsep penjumlahan.

\section{Analisis wawancara}

P : Assalamualaikum waroahmatuilahi wabarakaatu, bisa dimulai wawancaranya Nanang?

SP : Bisa kak

$\mathrm{P} \quad$ : Coba bacakan dulu soalnya

SP : (Siswa membaca soalnya)

$\mathrm{P} \quad$ : Apa yang ditanyakan di nomor 1 ini?

SP : Tentukan hasil penjumlahan

$\mathrm{P}$ : Coba jelasakan ini jawabanmu 
SP : Pertama saya kalikan dulu $3 x+2$ dengan $3 x+2$ habis itu yang ini kalikan lagi (sambil menunjuk angka $5 \mathrm{x}-2$ )

$\mathrm{P} \quad$ : Begini yah dek, saya jelaskan ulang. Jadi kalau ada soal seperti ini tidak usah dikalikan lagi. Kan yang diminta hasil penjumlahannya. Berarti $3 x+2$ ini kamu jumlahkan dengan $5 \mathrm{x}-2$ mengertimi?

SP : Iya kak

Berdasarkan kutipan wawancara di atas, dapat diketahui bahwa siswa tidak paham dengan konsep penjumlahan. Dan analisis hasil tes dan wawancara dapat disimpulkan bahwa siswa melakukan kesalahan konsep penjumlahan sehingga siswa mengerjakan soal dengan cara mengalikannya terlebih dahulu.

\section{Soal Nomor 3}

\section{Analisis Hasil Tes}

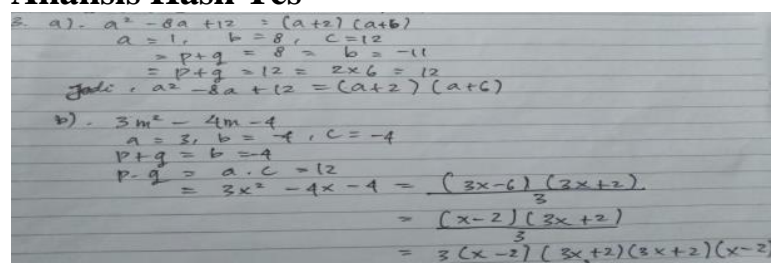

Dari jawaban siswa tampak bahwa siswa melakukan kesalahan konsep pada soal nomor 3a. Siswa salah dalam menuliskan nilai b. hal ini mungkin karena siswa tidak teliti dalam mengerjakan soal.

\section{Analisis Wawancara}

P : Kalau nomor 3?

SP : Disuruh faktorkan

$\mathrm{P} \quad$ : Berapa nilai $\mathrm{a}, \mathrm{b}$, dan c untuk nomor $3 \mathrm{a}$

ini?

SP $: \mathrm{a}=1, \mathrm{~b}=-8$ kalau $\mathrm{c}=12$

$\mathrm{P} \quad$ : kenapa dijawabanmu ini 8 ?

SP : Salah tulis itu kayaknya kak

$\mathrm{P}$ : Bagaimana maksudnya nomor $3 \mathrm{~b}$ ini hasil pemfaktorannya $(\mathrm{x}-2)(3 \mathrm{x}+2)$ $(3 x+2)(x-2)$ ?

$\mathrm{SP}$ : Oh itu maksudnya bisa $(3 \mathrm{x}+2)(\mathrm{x}-2)$ atau $(x-2)(3 x+2)$ hanya itu hasil saya lupa tulis kak.

Berdasarkan kutipan wawancara di atas, terlihat bahwa siswa sudah paham dengan pemfaktoran tetapi siswa kurang teliti sehingga siswa melakukan kesalahan konsep dalam mengerjakan soal tersebut. Dan analisis hasil tes dan analisis hasil wawancara dapat disimpulkan bahwa siswa melakukan kesalahan karena siswa tidak teliti dalam mengerjakan soal.

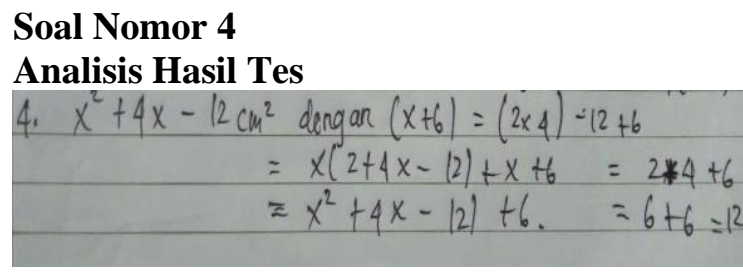

Dari jawaban siswa, tampak bahwa siswa melakukan kesalahan konsep Karena siswa mengerjakan soal tidak sesuai dengan apa yang dimaksud dan soal.

\section{Analisisi wawancara}

$\mathrm{P} \quad$ : Bagaiaman nomor 4 ?

SP : Saya tidak tahu kak saya tebak-tebak saja ini

$\mathrm{P} \quad$ : Tebak-tebak bagaimana? Coba baca dulu soalnya

SP : (Siswa membaca soal)

$\mathrm{P} \quad$ : Apa yang ditanyakan?

SP : Berapa lebar persegi panjang

$\mathrm{P} \quad$ : Jadi berapa lebarnya?

$\mathrm{SP} \quad: 2 \mathrm{x}+4 \mathrm{x}-12+6+4+6=12$

$\mathrm{P} \quad$ : Ha?? Kenapa bisa begitu?

SP : (Siswa diam)

Berdasarkan kutipan wawancara tersebut, terlihat bahwa siswa melakukan kesalahan konsep karena siswa tidak dapat mengubah permasalahan ke dalam model matematika sehingga siswa hanya menebak-nebak jawaban. Dan analisis hasil tes dan analisis wawancara dapat disimpulkan bahwa siswa melakukan kesalahan konsep karena siswa tidak paham apa yang dimaksud dalam soal sehingga siswa hanya menebak-nebak jawaban.

\section{Analisis Kesalahan Jawaban Siswa Nomor Subjek 2}

Soal Nomor 1

Analisis hasil Tes

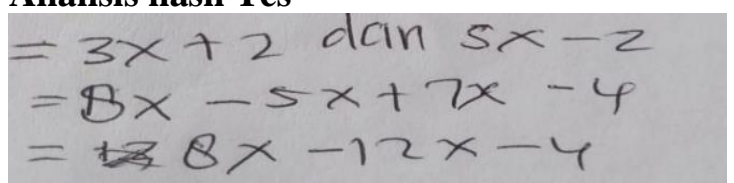

Dari jawaban siswa tampak bahwa siswa melakukan kesalahan konsep dalam melakukan operasi penjumlahan. Hal ini mungkin karena siswa tidak paham dengan maksud dan soal. 


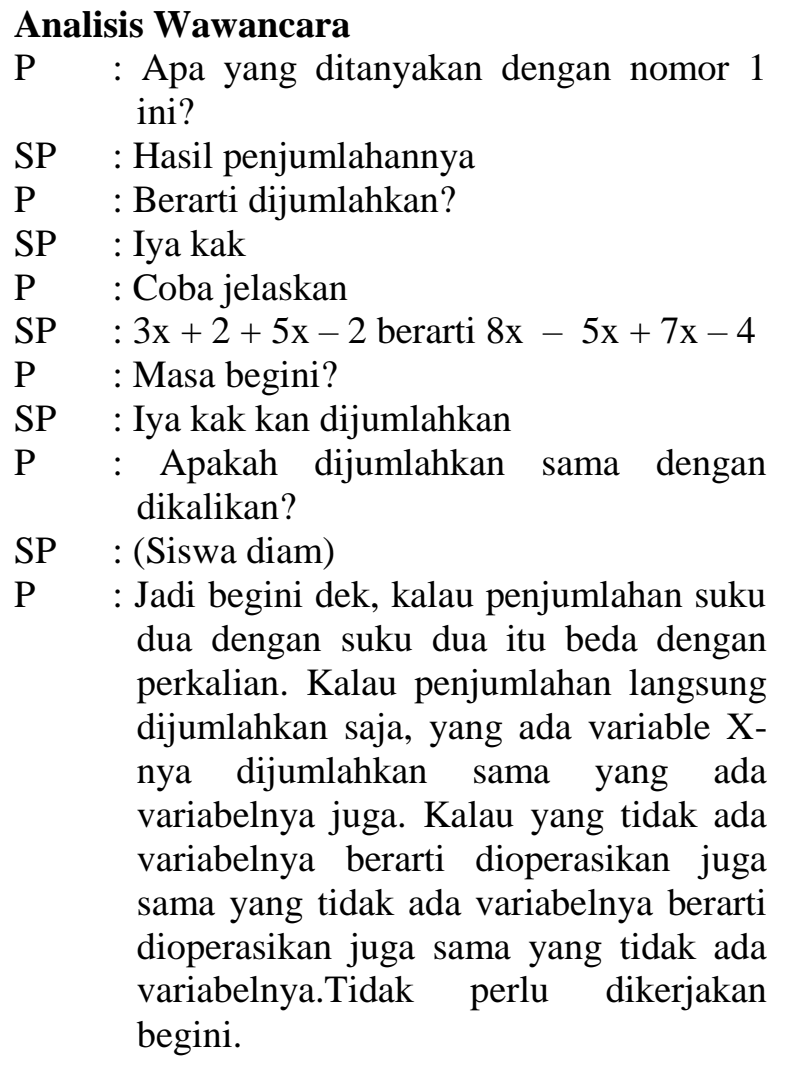

Berdasarkan kutipan wawancara tersebut, siswa mengerjakan soal penjumlahan seperti konsep perkalian. Dan analisis hasil tes dan wawancara dapat disimpulkan bahwa siswa melakukan kesalahan konsep penjumlahan. Siswa mengerjakan soal penjumlahan seperti konsep perkalian suku dua dengan suku dua. Hal ini karena siswa tidak paham dengan konsep penjumlahan.

\section{Soal Nomor 2}

\section{Analisis Hasil Tes}

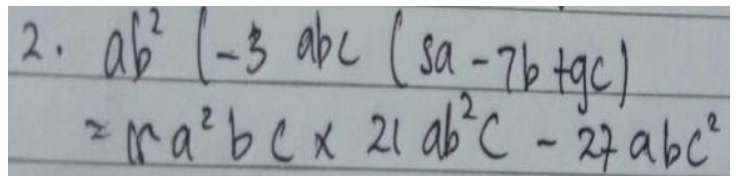

Dari jawaban siswa tampak bahwa siswa melakukan kesalahan prinsip karena siswa salah dalam perkalian tanda. Hal ini mungkin disebabkan karena siswa belum paham dengan konsep perkalian tanda.

\section{Analisis Wawancara}

$\mathrm{P} \quad$ : Lanjut soal nomor 2, bagaimana?

SP : Dikalikan satu-satu dengan yang didalam kurung.

$\mathrm{P} \quad$ : Oh begitu, jadi maksudnya jawabanmu ini bagaimana? Hasil perkaliannya ini
$15 \mathrm{a}+21 \mathrm{~b}+27 \mathrm{c}$ atau $15 \mathrm{a}^{2} \mathrm{bc}+21 \mathrm{ab}^{2} \mathrm{c}$ $+27 \mathrm{abc}^{2}$ ?

SP $\quad: 15 a^{2} b c+2 l a b^{2} c+27 a b c^{2} k a k$

$\mathrm{P} \quad$ : O begitu yah? Kenapa tidak dihapus saja kalau memang salah yang ini?

SP : Saya lupami kak

P : Sebelumnya saya Tanya dulu, kalau bilangan posotif dikalikan dengan bilangan negatif hasilnya apa?

SP : (Siswa bingung)

P : Kalau begitu saya kasih contoh, berapa hasilnya -5 × 6 ?

SP : $-30 \mathrm{kak}$

$\mathrm{P} \quad$ : Iya betul, terus kenapa ini jawabanmu $3 \mathrm{a} \times 5 \mathrm{abc}=15 \mathrm{a}^{2} \mathrm{bc}$ bukan $-15 \mathrm{a}^{2} \mathrm{bc}$ ?

SP : Saya buru-buru itu bu makanya saya tulis saja begitu.

Dan kutipan wawancara di atas, terlihat bahwa siswa sudah paham dengan perkalian tanda tetap siswa kurang teliti saat menyelesaikan butir soal. Dan analisis hasil tes dan analisis wawancara dapat disimpuikan bahwa siswa melakukan kesalahan prinsip dalam menyelesaikan butir soal disebabkan karena siswa terburu-buru sehingga siswa kurang teliti dalam menulis jawaban hasil akhir.

\section{Soal Nomor 3}

\section{Analisis Hasil Tes}

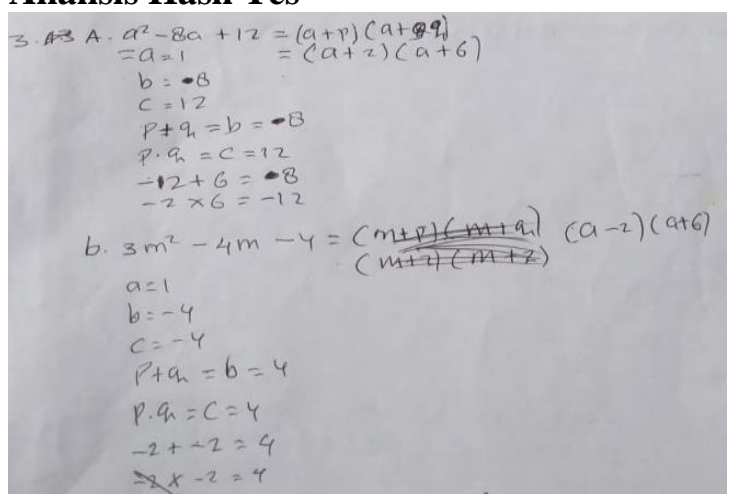

Dari jawaban siswa pada soal 3a tampak bahwa siswa melakukan kesalahan dalam menuliskan nilai $\mathrm{p}$ dan $\mathrm{q}$ meskipun rumusnya sudah benar dan pada soal $3 \mathrm{~b}$ siswa melakukan kesalahan prinsip yakni salah dalam menuliskan rumus $\mathrm{p}+\mathrm{q}$ dan $\mathrm{p} . \mathrm{q}$ untuk bentuk aljabar dengan $a \neq 1$ dan juga salah dalam mengoperasikan penjumlahan untuk menentukan nilai $\mathrm{p}$ dan $\mathrm{q}$.

\section{Analisis Wawancara}

$\mathrm{P} \quad$ : Bagaimana maksudnya ini nomor $3 \mathrm{a}, \mathrm{p}+$ $\mathrm{q}=\mathrm{b}=-8$ dan $\mathrm{p} \cdot \mathrm{q}=\mathrm{c}=12$ terus $-2+6$ $=-8$ dan $-2 \times 6=12$ ? Bisa jelaskan?

$\mathrm{SP} \quad$ : Untuk mencari nilai $\mathrm{p}$ dan $\mathrm{q}$ 
$\mathrm{P} \quad$ : Mencari nilai $\mathrm{p}$ dan $\mathrm{q}$ ?

SP : Iya, kalau $\mathrm{p}+\mathrm{q}-8$ berarti $\mathrm{p}-\mathrm{nya} 2, \mathrm{q}=-6$

$\mathrm{P} \quad$ :Masa? 2+ $(-6)=2-6+8$ ?

SP : (Siswa bingung) -4 harusnya c

$\mathrm{P} \quad$ : Kalau -4 berarti tidak bisa di ambil itu nilai $\mathrm{p}$ dan $\mathrm{q}$ coba kamu hitung ulang. Angka berapa kira-kira kalau dikalikan hasilnya 12 tapi dijumlahkan hasilnya -8

SP : Oh berarti jawabannya -2 dengan -6 toh kak?

$\mathrm{P} \quad$ : Coba kamu jumlahkan terus kalikan

SP : Kalau $2+(6)=-8$ terus $-2 \times-6=12$

$\mathrm{P} \quad$ : Tenis bagaimana dengan $3 \mathrm{~b}$ ?

SP : Sama dengan 3a kak

Berdasarkan kutipan wawancara di atas, terlihat bahwa siswa melakukan kesalahan prosedur pada soal $3 \mathrm{~b}$. dan hasil analisis tes dan analisis wawancara, dapat disimpulkan bahwa siswa sudah paham dengan konsep penfaktoran untuk bentuk aljabar dengan $\mathrm{a}=1$ tetapi untuk $a \neq 1$ siswa tidak bisa mengerjakan. Hal ini karena siswa belum paham dengan penfaktoran bentuk $\mathrm{ax}+\mathrm{bx}+\mathrm{c}$ dengan $\mathrm{a} \neq 1$.

\section{Analisis Kesalahan Jawaban Siswa Nomor Subjek 5}

\section{Soal Nomor I}

\section{Analisis Hasil Tes}

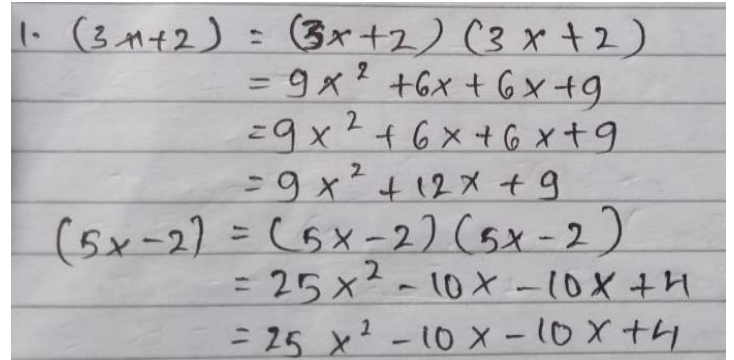

Dari jawaban siswa, tampak bahwa siswa melakukan kesalahan konsep penjumlahan. Hal ini mungkin karena siswa tidak paham dengan apa yang dimaksud dalam soal.

\section{Analisis Wawancara}

$\mathrm{P} \quad$ : Bisa bacakan soal nomor 1 ?

SP : (Siswa membaca soal)

$\mathrm{P} \quad$ : Apa yang ditanyakan

SP : Tentukan hasil penjumlahan

$P$ : Nah kan yang ditanyakan hasil penjumlahan. Maksudnya bagaimana $(3 x+2)(3 x+2)$ dengan $(5 x-2)(5 x-$ 2) ini?

SP : Saya kalikan dulu baru saya jumlahkan
P : Kenapa kamu kalikan? Kan yang ditanyakan penjumlahan bukan perkalian?

SP : (Siswa diam)

Berdasarkan kutipan wawancara di atas, tampak bahwa siswa melakukan kesalahan dalam mengoperasikan penjumlahan. Hal ini disebabkan karena siswa tidak paham dengan konsep penjumlahan. Berdasarkan analisis hasil tes dan analisis wawancara dapat disimpulkan bahwa siswa salah dalam mengerjakan soal disebabkan karena siswa tidak memahami konsep dasar operasi penjumlahan aljabar.

\section{Soal Nomor 2}

\section{Analisis Hasil Tes}

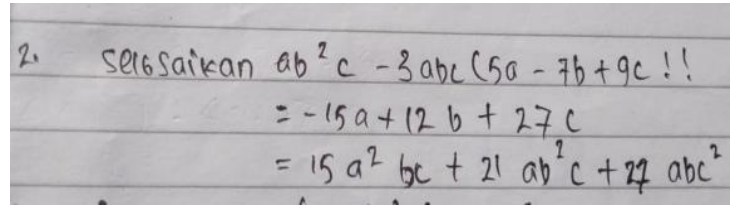

Dari jawaban siswa tampak, bahwa siswa melakukan kesalahan prinsip karena salah dalam mengoperasikan bilangan positif dan negatif. Hal ini mungkin disebabkan karena siswa tidak paham dengan perkalian tanda.

\section{Analisis Wawancara}

$\mathrm{P} \quad$ : Bagaimana kalau nomor 2 ini?

SP : Saya kalikan satu-satu kak

$\mathrm{P}$ : Bagaimana maksudnya dikalikan satusatu?

Sp : - -3abc saya kalikan dengan 5a habis itu saya kalikan dengan $7 \mathrm{~b}$ habis itu dengan $9 \mathrm{c}$

$\mathrm{P} \quad$ : Jadi berapa hasilnya?

SP $:-15 a^{2} b c+21 a b^{2} c-27 a b c^{2}$

$\mathrm{P} \quad$ : Kenapa dijawabanmu kamu tulis $15 \mathrm{a}^{2} \mathrm{bc}$ $+21 a b^{2} c-27 a b c^{2}$

SP : Saya salah tulis bu soalnya itu hanya saya buru-buru

P : Oh jadi karena buru-buru

Berdasarkan kutipan wawancara di atas, terlihat bahwa siswa melakukan kesalahan pada perkalian tanda karena siswa kurang teliti dalam mengerjakan soal. Dan hasil analisis tes dan analisis wawancara, dapat dilihat bahwa siswa sudah paham dengan perkalian tanda tetapi siswa kurang teliti dalam mengerjakan soal sehingga dapat disimpulkan bahwa siswa melakukan kesalahan prinsip. 
Soal Nomor 3

Analisis Hasil Tes

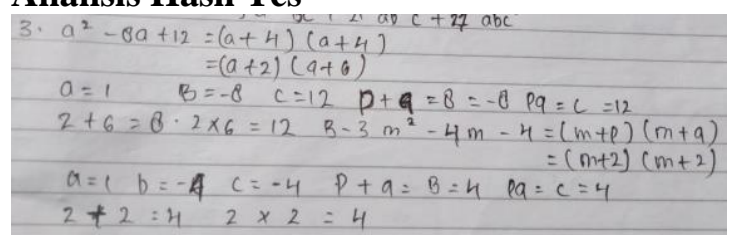

Dari jawaban siswa pada soal nomor $3 a$ tampak bahwa siswa melakukan kesalahan konsep dalam mensibtitusikan nilai $p$ dan $q$. hal ini mungkin karena siswa kurang teliti. Pada soal 3b tampak bahwa siswa melakukan kesalahan prosedural dalam menuliskan rumus $\mathrm{p}+\mathrm{q}$ dan $\mathrm{p}$. q. Hal ini mungkin karena paham dengan penfaktoran bentuk aljabar $\mathrm{ax}^{2}+\mathrm{bx}+\mathrm{c}$ dengan a $\neq 1$.

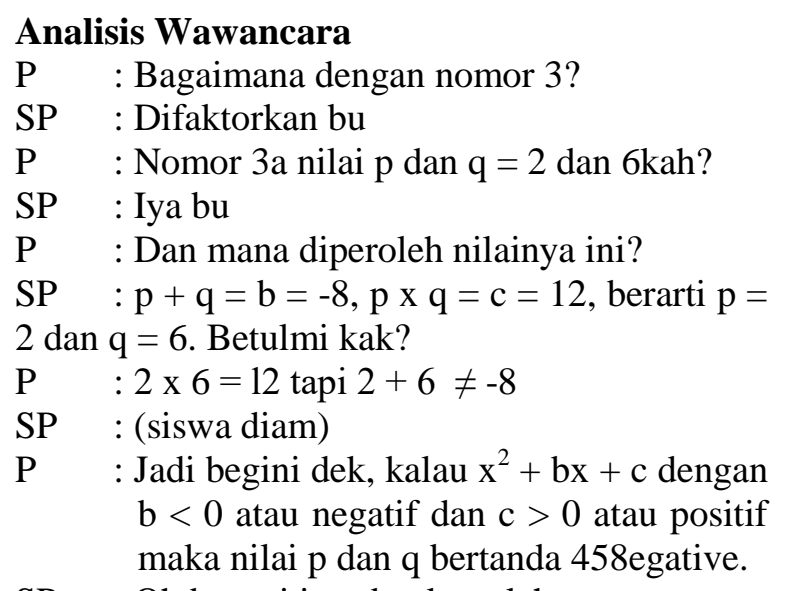

SP : Oh berarti jawabanku salah.

$\mathrm{P} \quad$ : Apakah nomor $3 \mathrm{~b}$ ini kamu kerjakan sama dengan $3 \mathrm{a}$ ?

SP : Iya kak kan disuruh faktorkan.

Berdasarkan kutipan wawancara diatas, pada soal 3a terlihat bahwa siswa melakukan kesalahan dalam prosedur penfaktorkan. Hal ini disebabkan karena siswa tidak teliti dalam mensibtitusikan nilai $\mathrm{p}$ dan q. pada soal $3 \mathrm{~b}$ siswa melakukan kesalahan Karena tidak paham dengan konsep penfaktoran bentuk aljabar $\mathrm{ax}^{2}+$ $\mathrm{bx}+\mathrm{c}$ dengan $\mathrm{a} \neq 1$. Dan analisis hasil tes dan analisis wawancara dapat disimpulkan bahwa siswa kurang teliti dalam mengerjakan soal dan juga siswa tidak paham dengan konsep penfaktoran bentuk aljabar $\mathrm{ax}^{2}+\mathrm{bx}+\mathrm{c}$ dengana $\neq 1$.

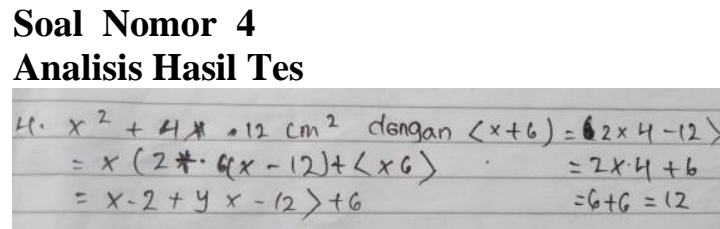

Dari jawaban siswa, tampak bahwa siswa tidak menuliskan apa yang diketahui dan apa yang ditanyakan dalam soal dan juga siswa melakukan kesalahan konsep. Hal ini mungkin disebabkan karena siswa tidak paham dengan maksud dan soal.

\section{Analisis Wawancara}

P : Coba bacakan Soal Nomor 4

SP : (Siswa membaca soal)

$\mathrm{P}$ : Apa yang diketahui dalam soal

SP : Luas persegi panjang

$\mathrm{P} \quad$ : Itu saja?

SP : Panjang

$\mathrm{P}$ : Panjang apa?

SP : Persegi panjang kak

$\mathrm{P} \quad$ : Apa yang ditanyakan?

SP : Berapa lebar persegi panjang

$\mathrm{P}$ : Bagaimana rumusnya untuk menentukan lebar

SP : (Siswa diam)

$\mathrm{P}$ : Bagaimana kah rumus persegi panjang?

SP : Panjang x Lebar

$\mathrm{P}$ : Bagaimana kalau yang ditanyakan lebar persegi panjang?

SP : (Siswa diam)

$\mathrm{P}$ : Bagaimana ini maksusnya jawabanmu? Bisa jelaskan?

SP : Saya lihat jawabanya teamanku itu kak

$P$ : Kenapa lihat jawaban teman? belum pernah diajar mengenai persegi panjang kah?

SP : Sudah kak tapi soalnya bukan yang begini

Berdasarkan kutipan wawancara di atas, tampak bahwa siswa melakukan kesalahan konsep karena siswa mengerjakan soal tidak sesuai dengan apa yang ditanyakan dalam soal. Dan analisis hasil tes dan analisis wawancara, dapat disimpulkan bahwa siswa melakukan kesalahan konsep. Hal ini karena siswa mengerjakan soal tidak dengan apa yang ditanyakan dalam soal dan juga siswa tidak terbiasa mengerjakan soal yang beragam.

\section{Hasil Wawancara Dengan Guru}


Berdasarkan hasil wawancara dengan guru diperoleh sebagai berikut:

1. Siswa menunjukan sikap berminat pada saat pembelajaran matematika berlangsung. Hanya sebagian siswa saja yang kurang minat dalam mempelajari materi operasi aljabar, hal ini terlihat dan keaktifan siswa saat mengikuti proses pembelajaran berlangsung.

2. Dalam mempelajari materi operasi aljabar, bagian yang dianggap sulit adalah masalah tentang cara menyelesaikan operasi aljabar, cara memfaktorkan dan masih banyak juga yang belum hafal kali-kali. Kemudian kalau diberikan soal yang berbeda dengan contoh soal, biasanya mereka bingung mengerjakannya.

3. Tindakan yang dilakukan guru dalam mengatasi kesulitan dalam mempelajari materi operasi aljabar adalah biasanya guru mengulangi beberapa penjelasan pada bagian yang sulit tersebut, setelah itu siswa diberi soal dengan model yang sama lalu disuruh untuk dikerjakan dan dipresentasekan di papan tulis.

4. Dan 4 orang siswa yang dijadikan subyek penelitian, ada 3 orang yang dianggap bisa yaitu Ersan Saputra, Della Indriani Ashar dan Nur Muhamad tapi Nur muhamad ini jarang hadir sehingga ia sering kali ketinggalan beberapa pokok bahasan.

5. Metode yang digunakan guru dalam mengajar adalah metode ceramah, Tanya jawab dan pemberian tugas.

\section{Pembahasan}

Dari hasil analisis data yang meliputi reduksi data, penyajian data, dan verifikasi atau pengecekan data diperoleh jenis-jenis kesalahan yang dilakukan siswa dalam menyelesaikan soalsoal pada materi operasi aljabar sebagai berikut: Kesalahan dalam memahami konsep

Kesalahan konsep adalah kesalahan yang dilakukan siswa dalam menafsirkan istilah, konsep, dan prinsip, Kastolan (Sumalwan, 2014: 45). Indikator kesalahan konsep menurut Kastalon (Sumalwan, 2104: 45) adalah (1)salah dalam menentukan rumus atau teorema atau definisi untuk menjawab suatu masalah, (2) penggunaan rumus, teorema, atau definisi yang tidak sesuai dengan kondisi prasyarat berlakunya rumus, teorema, atau definisi tersebut, (3) tidak menuliskan rumus, teorema atau definisi untuk menjawab suatu masalah.

Menurut Seodjadi (2000: 13) Kesalahan konsep adalah kekeliruan dalam menggolongkan atau mengklasifikasikan sekumpulan objek. Kesalahan ini ditandai dengan kesalahan atau kesulitan siswa dalam menyelesaiakan soal-soal operasi hitung pada operasi aljabar. Kesalahankesalahan tersebut terjadi karena kurangnya pemahaman siswa terhadap konsep dasar yang akan digunakan dalam operasi hitung operasi aljabar. Siswa mengalami kesulitan pada saat mengerjakan operasi penjumlahan seperti yang terjadi pada siswa SP-29 soal nomor I siswa mengoperasikan penjumlahan seperti perkalian suku dua dengan suku dua yang seharusnya siswa Langsung menjumlahkan saja dengan mengelompokkan suku yang sejenis. Selanjutnya siswa SP-05 dan siswa SP-30 menggunakan cara seperti ini untuk mengerjakan operasi penjumlahan bentuk aijabar $3 \mathrm{x}+2+5 \mathrm{x}-2=$ $(3 \mathrm{x}+2)(3 \mathrm{x}+2) 9 \mathrm{x}^{2}+12 \mathrm{x}+9$ dan $(5 \mathrm{x}-2)(5 \mathrm{x}$ $-2)=25 x^{2}-10 x-10 x+4$. Terlihat bahwa siswa melakukan operasi penjumlahan yang salah. setelah dilakukan wawancara terhadap siswa tersebut, ternyata karena ia tidak paham dengan maksud dan soal. Hal ini disebabkan karena siswa tidak memahami konsep penjumlahan.

Kesalahan siswa dalam konsep pemfaktoran misalnya sebagian siswa tidak bisa membedahkan konsep pemfaktoran aljabar bentuk $a x^{2}+b x+c$ dengan $a=b$ dan bentuk aljabar $\mathrm{ax}^{2}+\mathrm{bx}+\mathrm{c}$ dengan $\mathrm{a} \neq 1$ meskipun sudah benar dalam menuliskan nilai $a, b$, dan $c$ sehingga siswa tersebut salah dalam menuliskan rumus $\mathrm{p}+\mathrm{q}$ dan rumus $\mathrm{p} x \mathrm{q}$ yang mengakibatkan siswa salah dalam menentukan hasil akhir seperti yang terjadi pada siswa SP-05

Kesalahan siswa dalam menentukan nilai a, b, dan c seperti yang terjadi pada SP-29 dan SP-30 butir soal nomor 3a. siswa menuliskan nilai b sama dengan 8 yang seharusnya -8 . Setelah dilakukan wawancara pada kedua siswa tersebut, ternyata karena kedua siswa tersebut terburu-buru dalam menyelesaikan butir soal sehingga mengakibatkan kesalahan dalam menentukan hasil akhir.

Kesalahan dalam menerapkan prinsip

Jenis kesalahan ini adalah kesalahan yang dilakukan síswa karena tidak dapat menggunakan sifat-sifat dan konsep-konsep lain yang diperlukan dalam menyelesaikan soal-soal 
matematika, Menurut Soedjadi (2013: 13) kesalahan prinsip adalah kekeliruan dalam mengaitkan beberapa fakta atau beberapa konsep. Contoh: kesalahan dalam menggunakan rumus ataupun teorema serta kesalahan dalam menggunakan prinsip-prinsip sebelumnya. Kesalahan prinsip yang dialami siswa dalam penelitian ini adalah kesalahan karena siswa salah dalam mengaitkan beberapa fakta atau rumus serta kesalahan dalam operasi penjumlahan dan perkalian misalnya pada siswa SP-29 soal nomor I, siswa menjawab soal seperti $(3 \mathrm{x}+2)(5 \mathrm{x}-2)=8 \mathrm{x}^{2}+6 \mathrm{x} \pm 6 \mathrm{x}+8=8 \mathrm{x}^{2}+2 \mathrm{x}$ +8 . Setelah dilakukan wawancara terhadap siswa tersebut, ternyata siswa belum memahami konsep menerjemahkan kalimat matematika dalam soal dan juga siswa tidak memahami konsep penjumlahan. Pada siswa SP-02 butir soal nomor 2, siswa sudah paham dengan konsep perkalian tetapi siswa salah dalam menuliskan soal dan siswa masih salah dalam mengoperasikan perkalian variable-variabel bentuk aljabar. Sebagian dan siswa mengalami kesalahan dalam memahami dan menerapkan prinsip pada operasi hitung aljabar disebabkan karena belum paham dengan perkalian tanda dan ketidak telitian siswa dalam menyelesaikan butir soal, seperti yang terjadi pada siswa SP-02 dan SP-05 butir soal nomor 2 siswa tersebut salah dalam melakukan operasi perkalian tanda.

Pada siswa SP-29 dan SP-02 butir soal nomor $3 \mathrm{~b}$, kedua siswa tersebut salah dalam mensubtitusikan nilai $\mathrm{p}$ dan q. Hal ini disebabkan karena kedua siswa tersebut tidak memahami konsep operasi perkalian dan penjumlahan. Siswa tidak bisa membedahkan konsep penfaktoran aljabar bentuk $\mathrm{ax}^{2}+\mathrm{bx}+\mathrm{c}$ dengan $\mathrm{a}=1$ dan aljabar bentuk $\mathrm{ax}^{2}+\mathrm{bx}+\mathrm{c}$ dengan $a \neq 1$ sehingga siswa tersebut salah dalam menuliskan rumus $\mathrm{p}+\mathrm{q}$ dan rumus $\mathrm{p} \times \mathrm{q}$. Kesalahan Algoritma (Prosedur)

Jenis kesalahan ini adalah kesalahan karena jawaban siswa dalam menyelesaikan soal tidak sesuai dengan prosedur. Gagne( dalam Ruseffendi,1996: 166) menyatakan bahwa skill meliputi operasi dan prosedur. Skill dalam matematika adalah prosedur atau operasi-operasi yang dapat digunakan dalam menyelesaikan soal-soal matematika. Menurut seodjadi (2000: 13), kesalahan operasi adalah kekeliruan dalam pengerjaan hitung, pengerjaan aljabar, dan pengerjaan dalam matematika yang lain. Contoh kesalahan dalam menjumlahkan, mengurangkan dan kesalahan dalam operasi matematika lainnya.

Berdasarkan analisis hasil tes, wawancara siswa dan wawancara dengan guru bahwa kesalahan yang dilakukan siswa dalam menyelesaikan soal tes materi operasi aljabar disebabkan karena (J) siswa tidak memahami konsep operasi hitung pada operasi aljabar, (2) siswa belum bisa membedahkan pemfaktoran aljabar bentuk $a x^{2}+b x+e$ dengan $a=1$ dan pemfaktoran aljabar bentuk $a x^{2}+b x+c$ dengan a $=\mathrm{I}$ dan pemfaktoran aljabar bentuk $\mathrm{ax}^{2}+\mathrm{bx}+\mathrm{c}$ dengan $a \neq 1$ (3)siswa kurang teliti dalam menyelesaikan butir soal (4) siswa terburu-buru dalam menyelesaiakan butir soal, (5) siswa kurang latihan dengan tingkat soal yang beragam.

Kesalahan yang dilakukan siswa dalam menyelesaikan soal operasi aljabar adalah kesalahan fakta, kesalahan konsep, kesalahan prinsip, dan kesalahan prosedur. Dan ke empat jenis kesalahan tersebut, kesalahan yang paling banyak dilakukan oleh siswa untuk keseluruhan butir soal adalah kesalahan konsep. Dapat dilihat pada tabel 4.5 jumlah siswa yang melakukan kesalahan dalam menyelsaikan soal operasi aljabar dan 30 siswa responden. Jumlah responden yang paling banyak melakukan kesalahan konsep adalah pada butir soal nomor 1 yakni 17 orang atau 70,83\% dan jumlah siswa yang mengikuti tes . Jumlah responden yang paling banyak melakukan kesalahan prinsip adalah pada butir soal nomor 3b yakni sebanyak 7 atau $29,17 \%$ dan jumlah siswa yang mengukuti tes. Sedangkan jumlah responden yang paling banyak melakukan kesalahan prosedural terdapat pada butir soal nomor 1 dan 3a yakni sebanyak 7 orang atau $29,17 \%$ dan jumlah siswa yang mengikuti tes. Pada soal nomor 4 tidak ada siswa yang melakukan kesalahan prosedur dan kesalahan fakta. Upaya yang dilakukan guru dalam mengatasi kesalahan siswa adalah berusaha menjelaskan ulang materi yang belum dipahami dan mengadakan remedial terhadap siswa yang banyak melakukan kesalahan dalam menyelesaiakan soal matematika.

\section{Simpulan dan Saran simpulan}

Berdasarkan analisis dan pembahasan serta mengacu pada perumusan masalah maka dapat diambil kesimpuin sebagai berikut: 
1. Jenis kesalahan yang dilakukan siswa kelas $\mathrm{VIII}_{\mathrm{D}}$ SMP Negeri 5 kendari dalam menyelesaikan soal-soal operasi aljabar adalah kesalahan fakta, kesalahan konsep, kesalahan prinsip dan kesalahan prosedural.

2. Faktor-faktor yang menyebabkan siswa kelas $\mathrm{VIII}_{\mathrm{D}}$ SMP Negeri 5 kendari melakukan kesalahan dalam menyelesaikan soal operasi aljabar yaitu siswa tidak memahami soal dengan baik, sehingga siswa tidak dapat menerjemahkan suatu permasalahan kedalam model matematika. Siswa kurang memahami bagaimana cara mengoperasikan bentuk aljabar (penjumlahan, pengurangan, pembagian, dan perkalian) dan siswa mengerjakan soal secara terburu-buru sehingga kurang memperhatikan hasil perhitungannya dan siswa kurang memahami soal atau tidak teliti dalam membaca soal maupun dalam mengerjakan soal.

\section{Saran}

Berdasarkan kesimpulan diatas, penulis memberikan beberapa saran untuk mengatasi kesalahan-kesalahan yang dilakukan siswa dalain menyelesaikan soal-soal operasi aljabar.

1. Dalam operasi belajar mengajar, hendaknya siswa memperhatikan apa yang diajarkan oleh gurunya dengan serius agar materi yang disampaikan biasa dimengerti oleh siswa. Selain itu, siswa harus Iebih banyak latihan soal yang beragam dan lebih teliti dalam membaca soal serta menghitung.

2. Untuk menjawab soal dengan baik, siswa sebaiknya berbanyak latihan dalam menyelesaikan soal. Terkhusus dalam soal operasi aljabar diperhatikan agar dalam menyelesaikan soal tidak mengalami kesulitan dan juga agar supaya jawaban Iebih mudah ketika hendak diperiksa.

3. Untuk menhindari kesalahan akibat ketidak telitian yang juga banyak dilakukan siswa, maka dalam menyelesaikan soal kegiatan memeriksa kembali atau koreksi diperlukan. Untuk itu, dalam proses pembelajaran siswa perlu dibiasakan untuk memeniksa kembali jawaban dan pekerjaan mereka.

Daftar Pustaka
Abdulrahman, M. (2003). Pendidikan Bagi Anak Berkesulitan Belajar. Jakarta: Rineka Cipta.

Adhitya Yusuf. (2015). Analisis Kesalahan Siswa SMF Kelas VII Dalam Menyelesaikan Masalah Matemarika Maten Segi Empat Ditinjau DanGaya Belajar. Skripsi. Semarang: Universita Negeri Semarang.

Armiati, (1994). Kesulitan Mahasiswa Pendidikan Matematika FP. MIPA IKIP Padang dalam Mempelajani Mata Kuliah Kalkulus. Pasca Sarjana IKIP Malang, Tesis S2, Surabaya.

Arikunto. (2010). Prosedur Penelitian. Jakarta: Rineka Cipta

Budiyono. (2003). Metodologi Penelitian Pendidikan. Surakarta: Sebelas Maret University Press.

Clemant, (1982). Jurnal of Research in mathematics Education. Rustom: NCTM.

Djamarah, S.B. (2000). Guru dan Anak Didik Dalam Interaksi Edukatif. Jakarta:Rineka Cipta.

Fathani, Abdul Hakim. (2009). Matematika Hakikar dan Logika. Jogyakarta: Ar-Ruz Media.

Fitriani, Andati A. (2016). Analisis Kesalahan Siswa Kelas VIII dalam Menyelesaikan Materi Operasi Aljabar di MTs Muhammadiyah 2 Gundasari Trenggalek. Tulungagung. Skripsi, tidak diterbitkan, Fakultas Tarbiyah dan Ilmu Keguruan Institue Agama Islam.

Gunawan, Imam. (2013). Metode Penelitian Kualitatif Teori Dan Praktek. Jakarta: Bumi Aksara.

Hidayati, Y. M. (2009). Analisis Proses Pembelajaran Matematika di SMA Negeri Surakarta. Tesis Magister, tidak diterbitkan, Unversitas Sebelas Maret. Surakarta.Tersedia;http://eprints.uns.ac.id /3870/1/138471008201006101.pdf. Diakses tanggal 25 September 2017.

Margono, S. (2004). Metodologi Penelitian Pendidikan. Jakarta: Rineka Cipta.. 
Mulyono Abdurrahnian. (2003). Pendidikan Bagi Anak Berkesulitan belajar.Jakarta: Rineka Cipta.

Malik, N. Q. (2011). Analisis Kesalahan Siswa Kelas VII SMP 4 Kudus dalam Menyelesaikan Soal Matematika pada Pokok Bahasan Segiempat. Semarang: Skripsi, tidak diterbitkan, FMIPA UNNES.

Tersedia:http://lib.unnes.ac.id/5289/1/767 9.pdf diakses pada tanggal 25 September 2017.

Prabowo Anandito Aga, (2014). Analisis Kesalahan Siswa Kelas X SMA 1 Islam Gamping Yogyakarta Dalam Menyelesaikan Soal Matematika Yang Bekaitan Dengan Bilangan Berpangkat Dan Bentuk Aka. Skripsi. Yogyakarta: Universitas Negeri Yogyakarta

Purwanto, M Ngalim. (2003). Psikologi Fendidikan. Bandung: Remaja Rosdakarya.

Purwoto. 2003. Starategi Pembelajaran Matematika. Surakarta: UNS press.

Soedjadi. R. 2000. Kiat Pendidikan Matematika di Indonesia. Jakarta: DirjenDikti Depdiknas

Sudia, Muhammad. (1995). Metode Induktif Dalam Mengajarkan Pokak Bahasan Bilangan Pangkat Rasional. Surabaya: Pasca Sarjana, IKIP Surabaya

Syafarudin. (2000). Analisis Kesulitan Siswa Dalam Menyelesaikan Pertidaksamaan Kuadrat. Skripsi, tidak diterbitkan, FKIP Unhalu. Kendari.

Syaiful Bahri Djamarah. (2002). Psikologi Belajar. Jakarta: Aneka Cipta.

Sudijono, A. (2004). Pengantar Statistik Pendidikan. Jakarta: Raja Grafindo Persada

Tim Penyusun Kamus Pusat Bahasa. (2007). Karnus Besar Bahasa Indonesia. Edisi Keliga. Jakarta: Balai Pustaka.

Haryati, T (2015). Analisis Kesalahan Siswa SMP Kelas VII dalam Menyelesaikan Soal Cerita Berdasarkan Prosedur Newman, Semarang; Universitas Negeri Semarang.
Sunandar. (2014). Analisis kesalahan dan kesulitan Siswa Dalam Menyelesaikan Soal Uraian Pokok Bahasan Trigonometri Kelas X IIS di SMA N 1 Rembang. Prosiding Mathematics and Science Forum 2014. Semarang

(2014). Metode Penelitian Kualitatif Kuantitatif dan $R \&$ D. Bandung: Alfabeta 